\title{
Study on Water Quantity and Quality-Integrated Evaluation Based on the Natural-Social Dualistic Water Cycle
}

\author{
Shouping Zhang ${ }^{1 *}$, Lina Hou ${ }^{2}$, Chuanjiang Wei', Xiangnan Zhou', Na Wei ${ }^{1}$ \\ ${ }^{1}$ State Key Laboratory of Simulation and Regulation of Water Cycle in River Basin, \\ China Institute of Water Resources and Hydropower Research, \\ Room 956, Building A, JIA No.1, Yu Yuantan South Road, Haidian District, Beijing 100038, P.R. China \\ ${ }^{2}$ Changjiang Institute of Survey Planning Design and Research, Wuhan 430010, China
}

Received: 10 March 2014

Accepted: 3 September 2014

\begin{abstract}
For this study we constructed an integrated evaluation model of water quantity and quality that couples the supply-demand balance system, water consumption balance system, and a simulation model of water quality. In order to realize the dual water supply, the constraint equation of dual water supply has been added in the supply-demand balance system. The water pollution-induced water shortage quantitative identification approach and the evaluation index of the proportion between social economic water consumption and ecological water use has been put forward to evaluate the satisfaction degree of ecological water use and water quality based on simulations of water quantity and quality. This study utilizes an application of the water quantity and quality evaluation model in the main stream of the Huangshui River (Qinghai, China). The evaluation results provide support for future water resource development and management as follows:

(1) the water quality-index water shortage rate of the entire area was $3.7 \%$ and in some local areas reached $25.7 \%$

(2) the proportion of ecological water use of each water resource partition were all more than $80 \%$

(3) although the ecological water demand in the rivers could be satisfied, the standard-reaching rate of water quality was very low due to the total pollutants not having been controlled.
\end{abstract}

Keywords: water quantity and quality integrated evaluation, water pollution-induced water shortage, ecological water use, natural-social dualistic water cycle

\section{Introduction}

The water resources assessment is one of the basic works of water resources sustainable utilization and protection. The United States formed a set of water resource assessment methods based on statistics during its first and second national water resource assessments in 1968 and 1978 [1]. UNESCO and WMO published some studies in

*e-mail: zsp19840625@163.com
1988 that promoted the process of water resource assessment. As a result of the urgency of the water crisis and pollution during the 1990s, water resource assessments received increasing attention. The joint regulation and control for water quantity and quality has been researched based on water resource management. However, only to a limited extent has the integrated evaluation of water quantity and quality been discussed in previous studies [2-5].

In China, formal precipitation and hydrological observation started in the early $20^{\text {th }}$ century, but the analysis and 
research of water quality did not begin until the 1960s. Because of the time difference, in the national water resources assessment in the 1980s water quantity and quality assessments were separated. However, although the importance of the water quantity and quality integrated evaluation has long been recognized and studied [6-9], the appropriate evaluation method has still not been established.

In recent years, water quantity and quality coupling model has received more and more attention, and applications in the integrated evaluation of water quantity and quality, as well as the statistical trend analysis, have been studied. Yangwen Jia et al. [10] constructed the water quantity and quality integrated evaluation model based on the hydrological process and its concomitant transport and transformation of pollutants, and used this application in the Yellow River Basin. To obtain pristine groundwater and reduce the impact of pumping on the aquifers, Cheng-Shin Jang et al. [11] established an irrigation management plan of sustainable groundwater in the Pingtung Plain, Taiwan, based on the spatial variability of water quality and quantity. $Z$. Jamshidzadeh et al. [12] analyzed the change of the groundwater level in the Kashan Basin in Central Iran, collected 21 samples, compared their physical and chemical indices with the safe drinking water standard of WHO, and provided an evaluation of the basin's condition of groundwater quantity and quality development and utilization conditions. Vassilios Pisinaras et al. [13] used the SWAT Model to evaluate the Kosynthos River watershed's runoff and pollution load under conditions of different land use changes and crop management. May Wu et al. [14] assessed the water quantity and quality changes of the upper Mississippi River basin under the situation of large-scale planting of bio-energy feedstock, and also by using the SWAT Model. A. Loukas [15] utilized statistical and trend analysis and evaluated the Pinios River's surface runoff and water quality, and in so doing provided support for the future sustainable utilization of water resources. The above-mentioned research studies all evaluated the water quantity and quality process from different perspectives, by using either a model or a statistical method. However, they did not fully consider the dualistic water cycle and its concomitant hydrochemistry process.

Along with continuous expansion of the social economic system, human activities today profoundly impact the water resources system and have even already changed its cycle evolution law. Considering the influence of human activities, Hao Wang $[16,17]$ put forward the natural-artificial dualistic driving mode theory. This theory has been used in different research studies such as the dualistic water cycle model [18-20]. The water resources evaluation method was based on the dualistic water cycle theory and model [21] and the water quantity and quality integrated evaluation of the river's ecological water demand based on the dualistic water cycle [22]. Although the research results based on dualistic water cycle theory are abundant, the applications of the theory in the water quantity and quality integrated evaluation field is still weak.

In this study, a water quantity and quality integrated evaluation model was constructed, which was coupled with the supply-demand balance system, the consumption bal- ance system and the water quality simulation model. The study explored the water quantity and quality integrated evaluation method based on the dualistic water cycle and its concomitant hydrochemistry process. The influences of the water quantity and quality change process on social economic water utilization and consumption, ecological water utilization, river ecological runoff, and water quality were analyzed. The main stream of the Huangshui River watershed (China) was used as an application example of the theory and model. This research can provide support for future sustainable utilization of water resources.

\section{Model and Approach}

\section{Model Framework}

The water quantity and quality integrated evaluation model, shown in Fig. 1, mainly consisted of a water supplydemand balance system, a water consumption balance system, and a water quality simulation system. The water supply-demand system led to obtaining the decision results of water allocation based on the nodes' water quantity and quality, and provided pollution discharge information to the water quality simulation system. The function of a water consumption balance system is to simulate a river's runoff process. The simulation results can then be used to evaluate the proportion between social economic water consumption and ecological water use. The water quality simulation system must simulate the water quality condition of the river water function area, and provide related information for the water supply-demand balance system. The evaluation model also includes a groundwater numerical simulation model that can offer an exploitable quantity upper limit and quality conditions for the groundwater to water supplydemand balance system.

The foundation of the evaluation model is a water quantity and quality network diagram consisting of nodes and connecting lines [23]. Compared with a traditional network diagram, the network diagram here has added the river water function area section and its water quality goal to evaluate the river's ecological water use.

\section{Supply and Demand Balance Analysis}

Supply-demand balance analysis systems use a linear programming method, and construct the water balance equations and constraint equations for each control node, reservoir and calculation unit in the system network diagram based on the principles of water balance and search the optimal value of the decision vector around the extreme value of the objective function. The objective function and main equations are as follows:

Objective function:

$$
\operatorname{Max}\left\{\sum_{l \in A} w_{l} q_{l}-\sum_{i \in Z} \sum_{u \in U} w_{u i m} m_{u i}\right\}
$$

Water balance equation of the reservoir:

$$
\sum_{l \in l i} q_{i}-\sum_{k \in O_{i}} q_{k}=\Delta V_{i} \quad i \in R
$$


Constraint equation of the reservoir capacity:

$$
V l_{i} \leq V_{i} \leq \text { Vup }_{i} \quad i \in R
$$

Water balance equation of the node:

$$
\sum_{l \in I i} q_{l}-\sum_{k \in O_{i}} q_{k}=0 \quad i \in N
$$

Constraint equation of river channel flow capacity:

$$
l_{l} \leq q_{l} \leq u p_{l} \quad l \in A
$$

Supply-demand balance equation:

$$
\begin{gathered}
w d_{u i}-\left(\sum_{l \in I i} q_{l 2 u}+g_{2 u}\right)=w d_{u i}-S_{u i}=m_{u i} \\
i \in Z \quad u \in U
\end{gathered}
$$

Water balance equation of calculation unit:

$$
\sum_{u \in U} S_{u i}-\sum_{k \in O_{i}} q_{k}=E_{i} \quad i \in Z
$$

Balance equation of groundwater:

$$
G W_{\text {end }}=G W_{s}+Q_{s}+Q_{c i}-\sum_{u \in U} g_{2 u}-Q_{e t}-Q_{c o}
$$

...where $N$ is the set of all nodes; $R$ is the set of all reservoirs; $Z$ is the set of all calculation units; $A$ is the set of all connecting lines that are between nodes, reservoirs, and calculation units (the connecting line here means river or channel); $U$ is the set of all water users; $O_{i}$ is the set of all downstream connecting lines of node $i$ (reservoirs $i$ or calculation unit $i) ; I_{i}$ is the set of all upstream connecting lines of node $i$ (reservoirs $i$ or calculation unit $i$ ); $w_{u i}$ is weight of the water user $u$ in $i$ calculation unit; $m_{u i}$ is water deficiencies of the water user $u$ of calculation unit $i, v_{i}$ is the water storage in a period of time in reservoir $i ; \Delta v_{i t}$ is the variable quantity of water storage in a period of time in reservoir $i$; $E_{i}$ is total of evaporation, seepage and water consumption quantity of calculation unit $i ; q_{l}$ is flow rate of connecting line $l ; l_{l}$ and $u p_{l}$ is lower and upper limit of flow capacity of connecting line $l$, respectively; $\operatorname{Vup}_{i}$ and $V l_{i}$ are the upper and lower limits of the capacity of reservoir $i$, respectively; $q_{12 u}$ is the water supply quantity for user $u$ from channel $l$; $g_{2 u}$ is the water supply quantity of groundwater for user $u$; Sui is the total water supply for user $u$ of calculation unit $i$; wdui is the water demand of user $u$ in $i$ calculation unit; $G W_{s}$ and $G W_{\text {end }}$ are the start and end storages in the period of groundwater reservoir, respectively; $Q_{s}$ is the total infiltration replenishment of precipitation and irrigation for the groundwater; $Q_{c i}$ is the lateral recharge for the underground runoff; $Q_{e i}$ is the evaporation of groundwater; and $Q_{c o}$ is the lateral outflow of the underground runoff. All the variables above are positive except $\Delta v_{i t}$.

When the supply-demand balance analysis system operates, it can complete the dual water supply by utilizing the information of the surface water quality, groundwater quality, and exploitable quantity originating from the water quality simulation model and the groundwater numerical model. According to previous study results [24], when the quality is better than standard III, the water can be utilized by all users; when its quality reaches standard IV, it can be used by industry, agriculture, and ecology; and if its quality reaches standard $\mathrm{V}$, then it can only be supplied to agriculture and ecology.

The constraint equation of dual water supply is as follows:

$$
\sum_{l \in I i} \sum_{u \in U} \sum_{w q \mid \notin w q_{u}} q_{12 u}+\sum_{u \in U} \sum_{w q_{g} \notin w q_{u}} g_{2 u}=0 \quad i \in Z(9)
$$

...where $w q_{l}$ is the water quality type in the channel, $w q_{g}$ is the groundwater quality type, and $w q_{u}$ is the set of water quality type required by user $u$. When $u$ is urban or rural life, the $w q_{u}$ should be less than 3 and when $u$ is industry, less than 4 , etc.

All the water quantity variables in equation (9) are positive. If equation (9) equals zero, then all the water quantity variables must be zero, which means the water in the

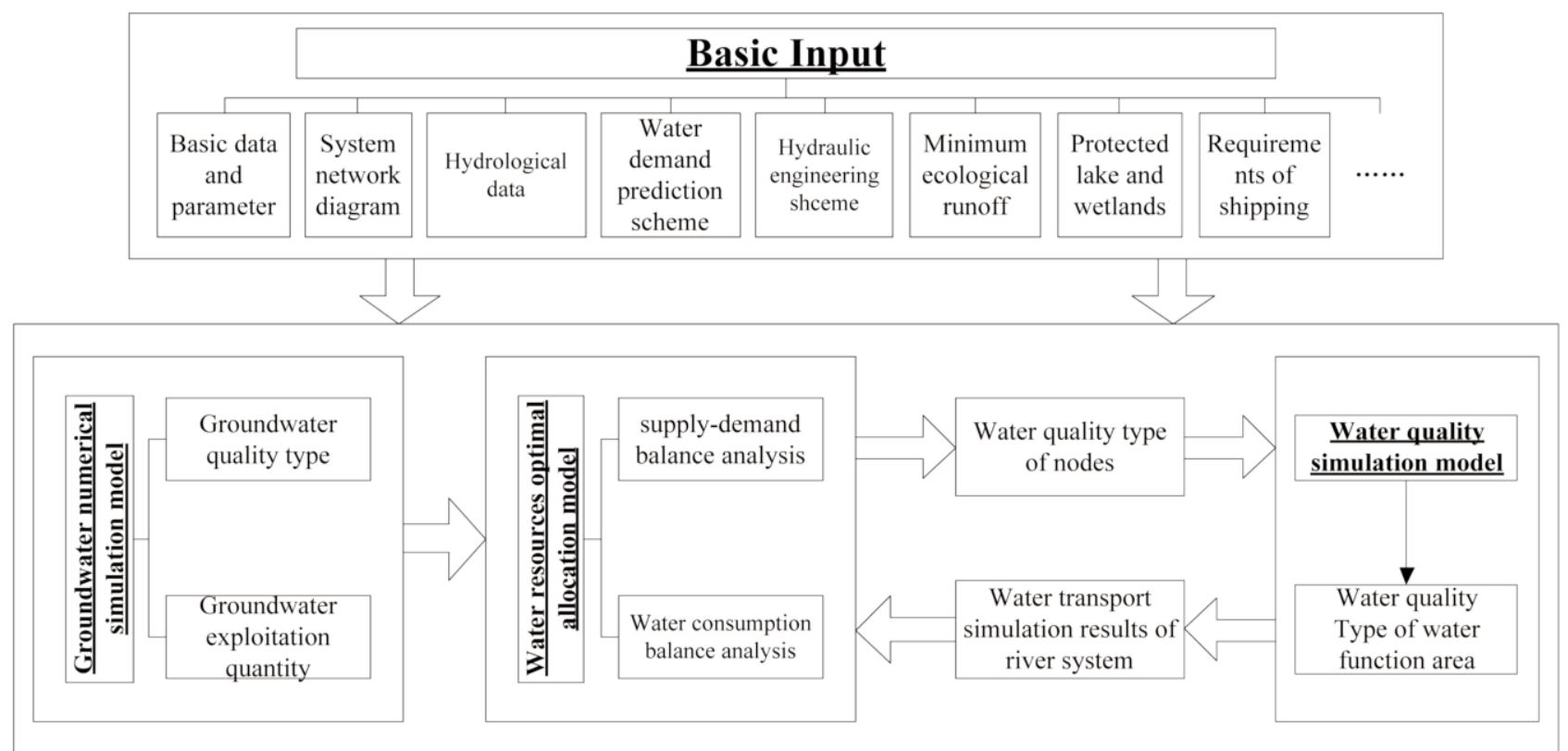

Fig. 1. Schematic diagram of water quantity and quality integrated evaluation model framework. 
channels and groundwater could not satisfy the water quality requirement of the users.

In order to improve the accuracy of the simulation effect, the supply-demand balance analysis model should be run on the water data in the recent five- to 10 -year period. The surface and underground water supply quantity should be calculated with reference to the supply and exploitation quantity data of the calculation unit in the most recent five- to 10 -year period. In the calculation unit without continual descent of groundwater level, the simulation result of the groundwater system should reach the balance of exploitation and supplement by adjusting the parameters, such as the infiltration replenishment coefficient and the phreatic evaporation coefficient, otherwise it should be consistent with the observed value.

\section{Water Consumption Balance Analysis}

The water consumption balance of water resource partition can be summarized as a dynamic balance around a partition's local water, water consumption, inbound water, outbound water, and transferring water [25]. The water consumption balance equation is as follows:

$$
\begin{gathered}
W_{b f}+W_{\text {in }}+D_{\text {in }}-W_{\text {enc }}-W_{\text {elc }}-R-D_{\text {ou }}=W_{\text {delta }} \\
W_{\text {elc }}=W_{\text {elcm }}+W_{\text {selc }}+W_{\text {gelc }}
\end{gathered}
$$

...where $W_{b f}$ is the local water of a partition; $W_{e n c}$ is the water consumption of social economics; $W_{\text {elc }}$ is the total water consumption of ecology, including artificial and natural ecology; $D_{\text {in }}$ is the transferring water coming from other basins; $D_{\text {оu }}$ is the water that transferred out of the partition; $R$ is the annual runoff of the basin outlet, including the surface inbound runoff and lateral outflow of underground runoff; $W_{\text {elcm }}$ is the ecological water consumption of the human water use process; $W_{\text {selc }}$ is the ecological water consumption in the river; and $W_{\text {gelc }}$ is phreatic evaporation.

The economic water consumption rate should be ascertained according to the statistical results of water supply, water use, water consumption, and draining water based on the artificial water cycle. By adjusting the parameters of each water resource partition until the water consumption rate of each water user are consistent with evaluation value, the model then can use those water consumption rates to calculate economic water consumption. A lake's water consumption should be calculated according to the statistical data of the lake and wetlands, and the change of water supply source.

The ecological water consumption of a basin should be calculated upon the calculation results of economic water consumption, taking the measured runoff and natural runoff data of the most recent 5 to 10 years as the basis. After the calculation of ecological water consumption, the river's runoff process and runoff volume based on the natural water cycle can be ascertained. The parameters of the different river's reach could be calibrated by comparing the simulated runoff process to the measured runoff process of the water quality survey section. In an area without a continual descent of the groundwater level, the annual average water storage variable would trend to zero. In the area of groundwater being over-exploited, the water storage variable should be comprehensively determined.

Water quantity and quality-integrated evaluation involves complex factors such as: evaporation consumption, water resource exploitation and utilization, industry and agriculture production, etc. When the evaluation model is running, errors will occur because the factors are so com-

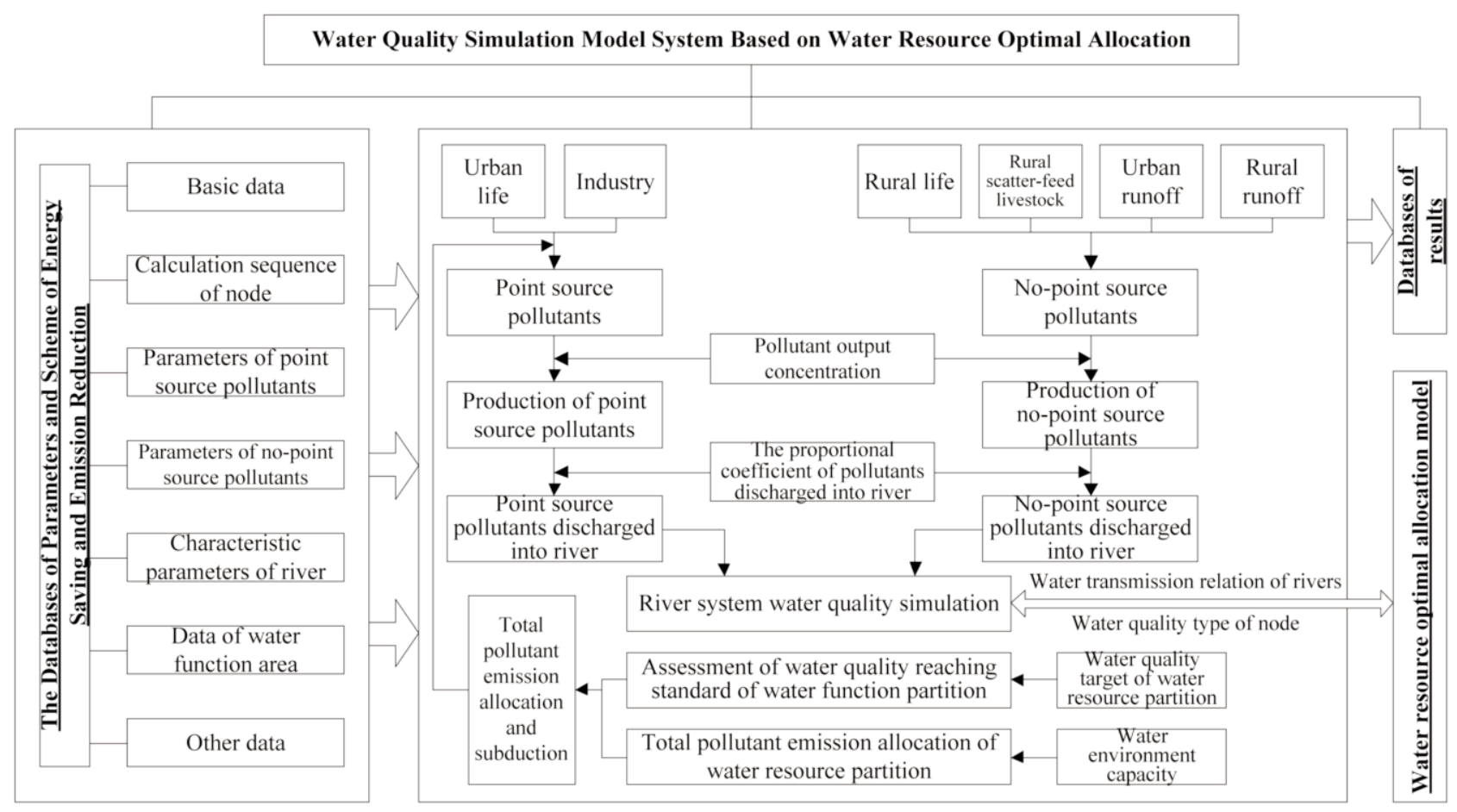

Fig. 2. Schematic diagram of water quality simulation model framework. 


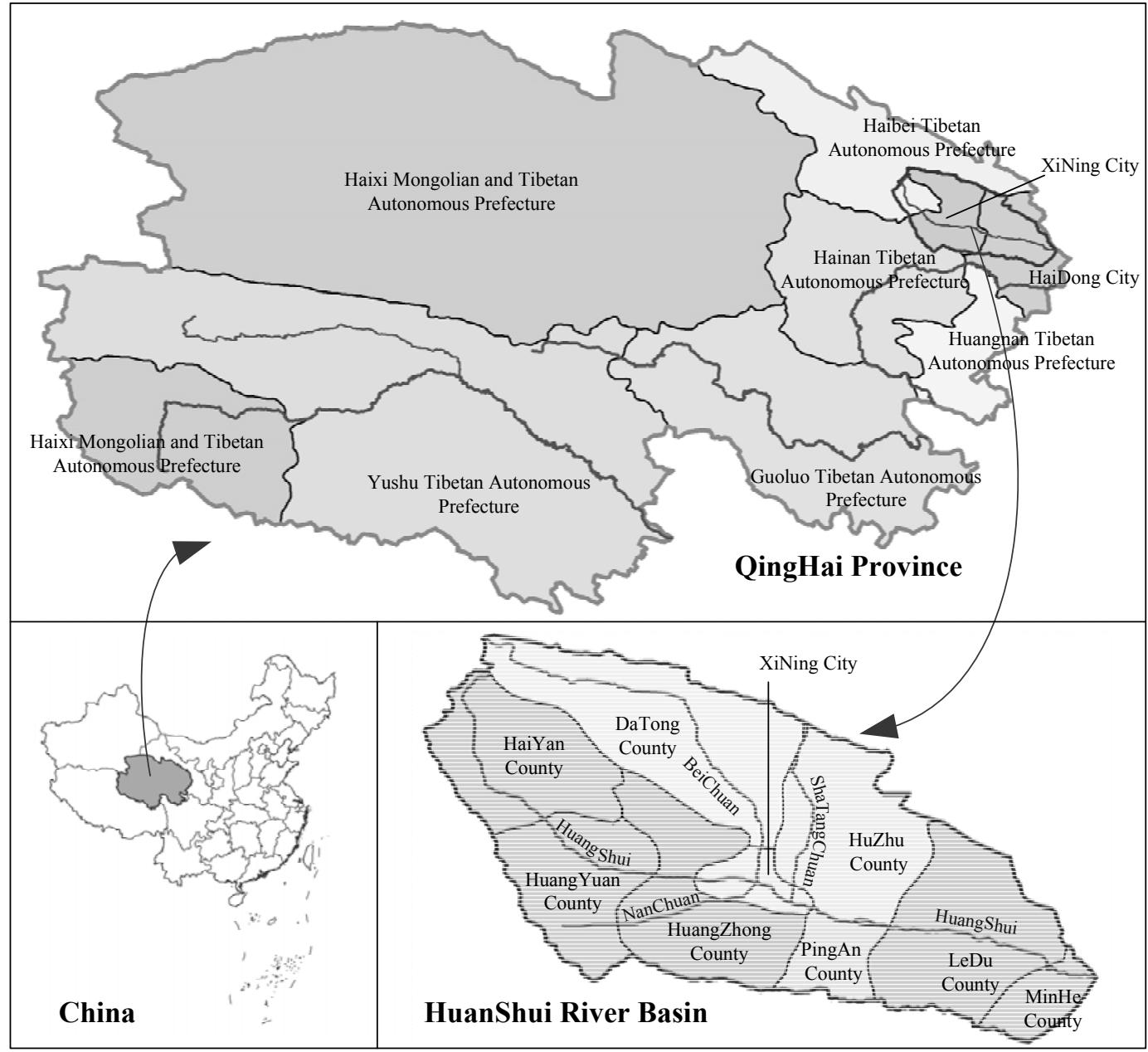

Fig. 3. Location map of the main stream of the Huangshui River.

plex, and all kinds of errors will gradually accumulate from the upstream area to the downstream area. In order to control the accumulation of errors and permit the simulation to reflect true conditions as much as possible, the water consumption balance should be analyzed on the basis of the water balance relationship and the measured runoff date of the control section.

\section{Water Quality Simulation Model}

The water quality simulation model, shown in Fig. 2, also uses one month as its time step, similar to the water quantity simulation model. Its functions mainly include: the simulation of point and non-point source pollutants production; the process simulation of pollutants entering into rivers; transport and transformation simulation of pollutants in rivers, lakes and reservoirs; and the reaching standard assessment of the water function area.

The quantities of point source pollutants into the river are equal to the products of the pollutant production multiplied by the river load ratio. The point source pollutant load could be estimated by using a quota method; the industrial pollutants should be determined by GDP, industrial water use and water discharge, and the domestic pollutants should be calculated by domestic water use and water discharge.
The river load ratio of pollutants may be obtained by typical investigation [26].

The quantity of non-point source pollutants discharged into the river caused by rainfall-runoff could be calculated by equation (12):

$$
L=C R T A
$$

...where $L$ is the quantity of non-point source pollutants into the river, $C$ is pollutant concentration, $R$ is the total runoff of the basin, $A$ is the basin area, and $T$ is the river load ratio of pollutants.

The transport and transformation equation of pollutants in the water [10] is as equation (13):

$$
\begin{gathered}
V_{1} C_{1}-V_{01} C_{01}=\left(Q_{0} C_{0}+R C_{R}+W_{P} C_{P}-W_{t} C_{t}\right)- \\
{\left[Q_{1} C_{1}+Q_{u} C_{u}+k\left(V_{1} C_{1}+V_{01} C_{01}\right) \Delta t / 2\right]}
\end{gathered}
$$

...where $\Delta t$ is the time step; $k$ is the degradation coefficient of pollutants; $Q_{0}$ is the inflow of the upstream; $C_{0}$ is the pollutant concentration of the upstream inflow; $Q_{1}$ is the outflow of the downstream; $\mathrm{C}_{01}$ and $\mathrm{C}_{1}$ are the pollutant concentrations of the downstream outflow in the start and end of the time segment, respectively; $V_{01}$ and $V_{1}$ are the water shortage at the start and end of the time segment, respec- 
tively; $R$ is local runoff; $C_{R}$ is the pollutant concentration of the local runoff $\left(C_{R}=L / R\right) ; W_{P}$ is the non-point source runoff; $C_{P}$ is the pollutant concentration non-point source runoff; $W_{\mathrm{t}}$ is the quantity of water that transferred out of the partition; $C_{\mathrm{t}}$ is the pollutant concentration of water transferred out of the partition; $Q_{u}$ is the quantity of local water diversion; and $C_{u}$ is the pollutant concentration of local water diversion. In the model, the pollutants in the river are supposed to be uniformly mixed $\left(C_{u}=C_{t}=C_{1}\right)$.

The model uses a single factor evaluation method to recognize water quality type. This means comparing the pollutant concentration of different pollutant indexes with the standards [24] and adopting the worst value as its water quality type.

\section{Water Quantity and Quality-Integrated Evaluation Method}

\section{Water Pollution-Induced Water Shortage Calculation}

Water pollution-induced water shortage refers to a social economic water shortage caused by water environmental pollution. The water quality could not satisfy the water users and the water resources could not be developed and utilized. A dual water supply is key to identifying the water pollution-induced water shortage. When analyzing the supplydemand balance, whether using the dual water supply equation is the discriminating standard of dual water supply. The dual water supply can be realized by adding the dual water supply equation to a supply and demand analysis system. Under the same conditions of water demand and engineering, the water pollution-induced water shortage is the difference of water shortage between dual water supply existing or not existing. When the supply-demand balance analysis system operates, the water shortage of each calculation unit can be obtained, as well as the water pollution-induced water shortage for each unit. Therefore, the water pollutioninduced water shortage of each administrative area and water resource partition can be recognized statistically.

\section{Assessment of Proportion between Economic Water Consumption and Ecological Water Use}

Traditional water saving usually takes the measures of reducing water demand to achieve its goal. Although the development of water-saving technology has already encouraged decreases in water demand, water consumption of the basin is still continually increasing, since reducing water demand is not a means of reducing water consumption. With the increase of water consumption, a series of problems has occurred such as the groundwater level dropping, a decrease in river runoff, and even rivers drying up.

Water consumption balance analysis and evaluation are important contents of the water resources evaluation [27, 28]. In order to assist in solving problems, the Agricultural Water-Saving Irrigation Project of the World Bank (2001$05)$ put forward the theory of evapotranspiration management $[29,30]$.
This research used the social economic water consumption rate and the proportion of ecological water use as the evaluation indexes of social economic water consumption and ecological water use conditions. The object of previous social economic water consumption evaluation could only be on the whole basin, but this time the object was also the water resource partition, which has inbound and outbound waters from both the upstream and downstream.

The equations are as follows [25]:

$$
\begin{gathered}
E_{c w}=W_{e n c} /\left(W_{b f}+W_{i n}+D_{i n}-D_{o u}\right) \\
E_{u}=1-E_{c w}
\end{gathered}
$$

...where $E_{c w}$ is the proportion of economical water consumption and $E_{u}$ is the proportion of ecological water use.

\section{Evaluation of Water Quantity and Quality in the River}

This study uses minimum or appropriate ecological flow as the standard, takes supply-demand and water consumption balance analysis models as tools, simulates the river flow under the conditions of recent water resource development and utilization, and judges whether the river flow could satisfy the demand of the ecological flow of the river. If the river flow is greater than the ecological flow demand, then the ecological water use could be satisfied. Otherwise, the ecological water use could not be satisfied.

In order to protect the water ecosystem, the water quantity and quality in a river all must reach the standard required by the water ecosystem. In China, the important rivers have already been classified into different water function area types [31, 32], and the water environment capacity of the water function area has already been researched [33]. This study uses the water quality requirement as the water quality standard, and the water environment capacity of the water function area as the standard of pollution gross control.

\section{Application}

\section{General Situation of Study Area}

The main stream of the Huangshui River in Qinghai, shown in Fig. 3, is the first grade tributary of the upper Yellow River, with a basin area of $16,120 \mathrm{~km}^{2}$ and length of $336 \mathrm{~km}$. The administrative areas involved include: Xining City, Haiyan County, Huangyuan County, Huangzhong County, Datong County, Huzhu County, Pingan County, Ledu County, and Minhe County of Qinghai Province. The water resource partitions involved include: upstream partition, Beichuan River partition, middle stream partition, and downstream partition. The water function partitions involved include eight first-grade partitions and 22 secondgrade partitions. The annual average total water resource of the basin is 22.88 hundred million $\mathrm{m}^{3}$, with the surface 
water resource of 21.61 hundred million $\mathrm{m}^{3}$. In 2010, the water supply ability of all types of water sources in the project was 11.98 hundred million $\mathrm{m}^{3} / \mathrm{a}$; the water quality of river reach below Datong County could only reach the standard from below $\mathrm{V}$ to $\mathrm{IV}$; the standard-reaching rate of water function partitions was only $44 \%$. The water pollution in midstream and downstream of the Huangshui River has already seriously affected its water resource utilization.

In previous studies [34] the principle and method of water quantity model generalization were discussed. This study is based on the previous research, and adds necessary monitoring sections of the water function partition and water quality when constructing the evaluation model according to the local water function partitions. The division rules of the calculation unit are nesting the water resource partitions with the administrative area, and dividing the industrial park and agricultural park into independent units. According to the division rules, the area is divided into 55 units.

\section{Water Quantity Balance Analysis}

\section{Supply-Demand Balance Analysis}

Although the water quality of the main stream in the current year was severely polluted, the water quality of each of the tributaries was better. In order to ensure the safety of water use, the domestic and most industrial users chose the tributaries as their water source, and the main stream was only used as the water source for agriculture. Therefore, in the main stream of the Huangshui River, the water pollution-induced water shortage only existed in agriculture, ecology and a small amount of industry. However, in the practical water supply process, the dual water supplies of industry, agriculture, and ecology were not strictly implemented according to the standard, as agriculture still used excessively polluted water. Therefore, ostensibly the influence of water environmental pollution on water resource development and utilization did not appear to be serious.

Based on the water resource development and utilization conditions of the current year, we performed analysis using the supply-demand balance analysis system, simulated monthly un-dual water supply, and finally obtained the supply-demand balance results of the water resources. In the datum year and under the annual average conditions, the total water demand was 12.37 hundred million $\mathrm{m}^{3}$, total water supply was 11.16 hundred million $\mathrm{m}^{3}$, total water shortage was 1.21 hundred million $\mathrm{m}^{3}$, and total water shortage rate was $9.7 \%$. The water supply for urban life was 0.58 hundred million $\mathrm{m}^{3}$, rural life was 0.53 hundred million $\mathrm{m}^{3}$. industry was 2.69 hundred million $\mathrm{m}^{3}$, and urban ecology was 0.43 hundred million $\mathrm{m}^{3}$.

\section{Water Consumption Balance Analysis}

The main focus of the water consumption balance analysis was simulating water consumption and the discharging processes of urban life and industry, which was based on the supply-demand balance and the wastewater of sewage outfalls discharged into the river.

In the current year the proportions of agricultural, industrial, and domestic water consumption in total economic water consumption were $77.3 \%, 11.7 \%$, and $10.9 \%$ in the study area, respectively.

Affected by Xining City and the industrial parks nearby, the upstream region had a higher economic development level and the largest proportion of domestic and industrial water consumption. In the midstream and downstream regions the economic development levels were lower and the proportion of agricultural water consumption was the largest.

The comprehensive coefficient of water consumption in the main stream of the Huangshui River was 0.52 , of which the coefficients of life, industry, and agriculture were 0.51 , 0.23 , and 0.62 , respectively.

The water quantity process simulation of all types of river sections, based on the measured runoff of each hydrological station, provides the basic runoff data for the water quality simulation. The annual average runoff process simulation results of the basin's outlet section are shown as Fig. 4. The annual average measured and simulated runoff were 14.11 and 13.48 hundred million, and the relative error was approximately $4.5 \%$.

\section{Water Quality Simulation}

When performing the simulation of the pollutants' production and pollutants entering the river, the point source pollutants should use monitoring value as its simulation reference, and the non-point source pollutants should use evaluation value.

In the study area the production quantity of COD, ammonia nitrogen, TP, and TN were $22.68 \times 10^{4} \mathrm{t}, 1.08 \times 10^{4} \mathrm{t}$, $5.83 \times 10^{4} \mathrm{t}$, and $4.85 \times \times 10^{4} \mathrm{t}$, respectively. From the perspective of pollution sources, the main pollution type in the study area was non-point source pollution. The production quantities of non-point source COD, ammonia nitrogen, TP, and $\mathrm{TN}$ accounted for $82.76 \%, 49.48 \%, 98.51 \%$, and $81.93 \%$ of each total production quantity, respectively.

The COD, ammonia nitrogen, TP, and TN quantities entering the river were $3.93 \times 10^{4} \mathrm{t}, 0.99 \times 10^{4} \mathrm{t}, 0.20 \times 10^{4} \mathrm{t}$, and $0.79 \times 10^{4} \mathrm{t}$, respectively. Compared with point source pollu-

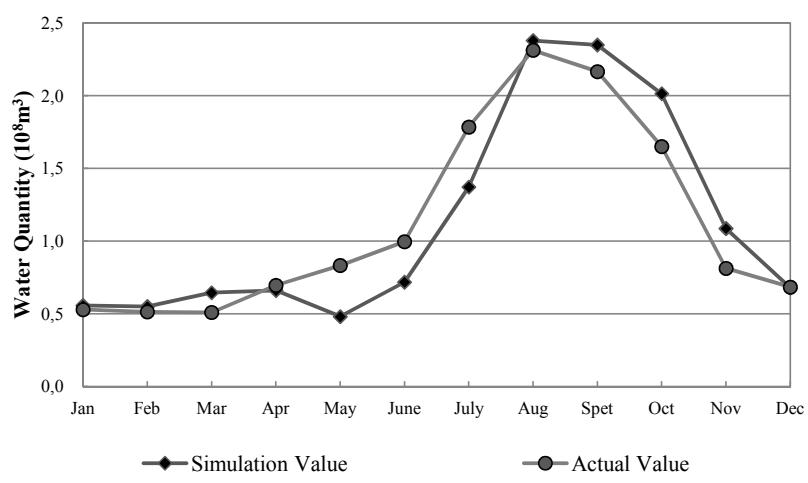

Fig. 4. Annual average runoff simulated result of the basin's outlet section. 
Table 1. Administrative area simulation result of point source pollutants into the river.

\begin{tabular}{|l|c|c|c|c|c|c|c|c|}
\hline \multirow{2}{*}{$\begin{array}{c}\text { Administrative } \\
\text { area }\end{array}$} & \multicolumn{4}{|c|}{ Evaluation value (t) } & \multicolumn{4}{c|}{ Simulation value (t) } \\
\cline { 2 - 10 } & COD & $\begin{array}{c}\text { Ammonia } \\
\text { Nitrogen }\end{array}$ & TP & TN & COD & $\begin{array}{c}\text { Ammonia } \\
\text { Nitrogen }\end{array}$ & TP & TN \\
\hline Haiyan & 1637.6 & 145.8 & 19.5 & 252.6 & 1637.1 & 145.7 & 19.5 & 252.5 \\
\hline Huangyuan & 2485.3 & 161.4 & 51.1 & 535.3 & 2366.1 & 153.7 & 48.6 & 509.4 \\
\hline Huangzhong & 2132.2 & 151.8 & 83.3 & 336.7 & 2031.4 & 144.6 & 79.0 & 320.5 \\
\hline Xining & 13951.9 & 2633.0 & 351.3 & 4005.5 & 13257.0 & 2505.9 & 334.9 & 3814.8 \\
\hline Datong & 3925.3 & 311.1 & 29.4 & 671.4 & 3905.0 & 309.3 & 29.2 & 667.3 \\
\hline Huzhu & 1746.4 & 215.5 & 91.0 & 368.6 & 1543.4 & 192.5 & 79.9 & 327.7 \\
\hline Pingan & 1355.3 & 230.8 & 25.6 & 111.5 & 1261.3 & 214.8 & 23.8 & 103.7 \\
\hline Ledu & 1861.3 & 217.8 & 17.3 & 313.2 & 1620.2 & 188.6 & 15.0 & 271.3 \\
\hline Minhe & 3200.4 & 338.2 & 28.7 & 458.9 & 2696.1 & 284.8 & 24.2 & 386.2 \\
\hline Total & 32295.7 & 4405.4 & 697.2 & 7053.7 & 30317.6 & 4139.9 & 654.1 & 6653.5 \\
\hline
\end{tabular}

tants, non-point source pollutants have a lower river load ratio. This is due to a longer time and distance before entering the river, as well as a higher degradation extent. Therefore, point source pollutants are determined to be the main pollutants entering the river. The point source COD, ammonia nitrogen, TP, and TN quantities entering the river accounted for $88.51 \%, 97.67 \%, 24.88 \%$, and $84.35 \%$ of each total quantity, respectively. The simulation results of the point source pollutants entering the river are shown in Table 1 .

In the study area, the point source pollutants mainly originated from Xining City and the surrounding areas, which have large population centers or relatively developed social economies. Non-point pollutants mainly come from midstream and downstream areas such as Huzhu, Pingan, Ledu, and Minhe counties. Due to the serious soil and water loss and the large amounts of non-point agricultural pollution in mountainside areas, the non-point pollutant production in Datong and Huanzhong were relatively higher. The pollution discharging from Xining City, Datong County, and Huangzhong County into the midstream and downstream of the Huangshui River caused the water quality to become worse.

As examples, the COD and ammonia nitrogen simulation results within the river are shown in Figs. 5 and 6. In this research, the pollutant fluxes of each monitoring section were taken as the reference for water quality simulation within the river. The reasons are as follows:

1) The water quality simulation model uses either a month or 10 days as the simulative time step

2) The runoff simulation also has errors

3) The representativeness of pollutant monitoring concentration in some time frames was faulty

4) The local area did not have any long series or monthly water quality monitoring data

The simulation errors of COD and ammonia nitrogen were below $7.6 \%$ and $3.4 \%$, respectively.

\section{Discussion}

\section{Identification of the Water Pollution-Induced Water Shortage}

Before predicting future water development and utilization, the source, engineering, and water pollution-induced water shortage of the current year should first be investigated. This study is mainly concerned with identifying the water pollution-induced water shortage. We based the study on the supply-demand balance, water consumption balance, and water quality simulation, and placed the surface and underground water quality simulation result into the supply-demand balance analysis system, keeping other parameters unchanged, which led to the dual water supply simulation. The water pollution-induced water shortage is the difference between dual water supply existing or not existing. Water pollution-induced water shortages of administrative areas are shown as Table 2.

In the study area, the total water pollution-induced water shortage was 45.31 million $\mathrm{m}^{3}$ and the water pollu-

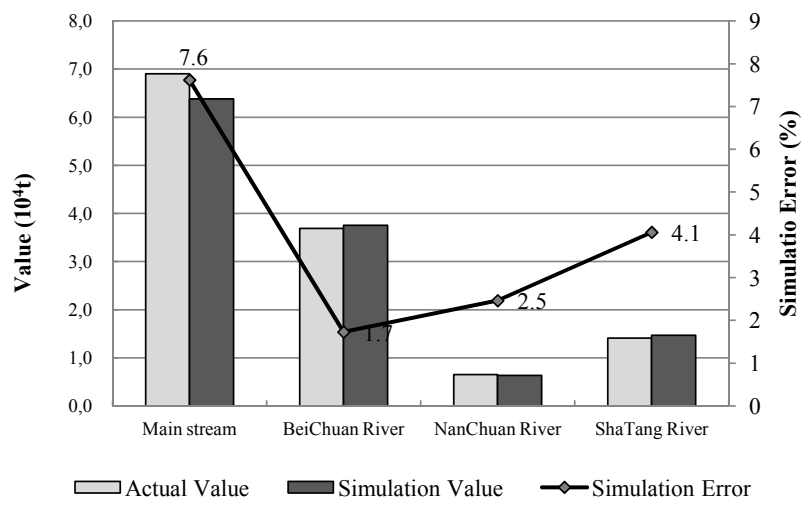

Fig. 5. COD flux simulation results of the main stream and important tributaries of the Huangshui River. 
Table 2. Water pollution-induced water shortages of administrative areas.

\begin{tabular}{|c|c|c|c|c|c|c|c|c|}
\hline \multirow{2}{*}{$\begin{array}{c}\text { Administrative } \\
\text { area }\end{array}$} & \multirow{2}{*}{$\begin{array}{c}\text { Water } \\
\text { demand } \\
\left(10^{4} \mathrm{~m}^{3}\right)\end{array}$} & \multicolumn{6}{|c|}{ Water pollution-induced water shortage $\left(10^{4} \mathrm{~m}^{3}\right)$} & \multirow{2}{*}{$\begin{array}{c}\text { Water } \\
\text { shortage rate } \\
(\%)\end{array}$} \\
\hline & & Urban life & Rural life & Industry & Agriculture & $\begin{array}{l}\text { Urban } \\
\text { ecology }\end{array}$ & Subtotal & \\
\hline Xining & 27766 & 0 & 0 & 360 & 209 & 0 & 569 & 2.0 \\
\hline Haiyan & 1993 & 0 & 0 & 0 & 0 & 0 & 0 & 0.0 \\
\hline Huangyuan & 8493 & 0 & 35 & 39 & 100 & 1 & 175 & 2.1 \\
\hline Huangzhong & 21488 & 0 & 0 & 1 & 0 & 0 & 1 & 0.0 \\
\hline Datong & 18651 & 0 & 0 & 0 & 0 & 0 & 0 & 0.0 \\
\hline Huzhu & 14562 & 0 & 0 & 0 & 0 & 0 & 0 & 0.0 \\
\hline Pingan & 6180 & 0 & 0 & 228 & 1232 & 129 & 1589 & 25.7 \\
\hline Ledu & 14416 & 0 & 56 & 294 & 1692 & 11 & 2053 & 14.2 \\
\hline Minhe & 10116 & 0 & 47 & 77 & 20 & 0 & 144 & 1.4 \\
\hline Total & 123665 & 0 & 138 & 999 & 3253 & 141 & 4531 & 3.7 \\
\hline
\end{tabular}

tion-induced water shortage rate was $3.7 \%$. Among all administrative areas, the water pollution-induced water shortage rate of Pingan County was the highest, which reached $25.7 \%$, and Ledu County took second place with $14.2 \%$. The influence of water pollution to Xining City, Huangyuan County, and Minhe County was high; however, in Haiyan County, Datong County, and Huzhu County the influence was low. In the midstream, the water pollutioninduced water shortage was 36.22 million $\mathrm{m}^{3}$ and the water shortage rate was $9.3 \%$. In the downstream, the water pollution-induced water shortage rate was $1.6 \%$. In the headwater and Beichuan river regions, the water pollutioninduced water shortage rate also was low. Generally speaking, in the midstream and downstream of the Huangshui River, the water pollution was serious and affected local water use. The water pollution-induced water shortage was mainly concentrated in agriculture, secondly in industry, and finally in rural life and ecology. Urban life has not yet shown a water pollution-induced water shortage.

Sources, engineering, and water pollution-induced water shortages all existed in the study area. In the higher

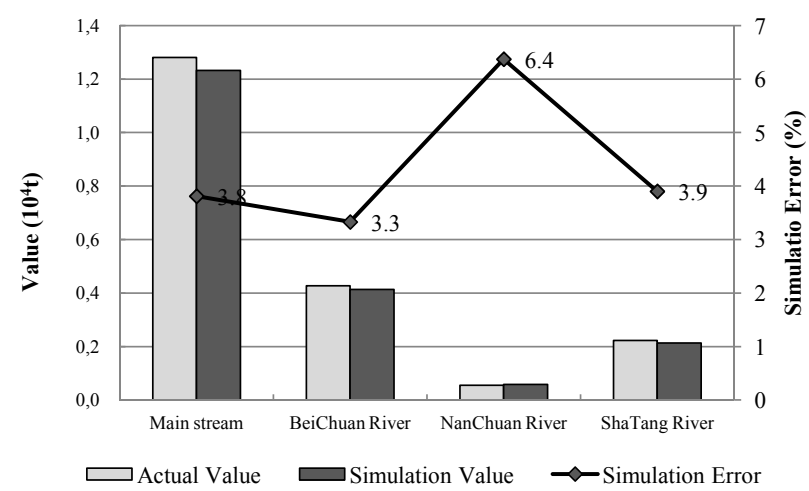

Fig. 6. Ammonia nitrogen fluxes simulation result of the main stream and important tributaries of Huangshui River. water shortage rate areas in Huangyuan, Huangzhong, and Huzhu counties, all water shortage was in agriculture, with the exception of an industrial water shortage of 8.53 million $\mathrm{m}^{3}$ in Ganhe Industrial Park in Huangzhong County. In Huangyuan County the results indicated there was mainly a source water shortage; in Datong and Huangzhong counties a local engineering water shortage was found; in Huzhu County there were both source and engineering water shortages evident; and in Pingan and Ledu counties, water pollution-induced water shortage was the most common.

\section{Proportion Analysis of Ecological Water Use}

The proportion of social economic water consumption of the water resource partitions roughly was $2.7 \%$ to $19.4 \%$. The highest were in the Beichuan River region and headwater region, which were $19.4 \%$ and $17.1 \%$. In other words, the lowest proportion of ecological water use, $80.6 \%$ and $82.9 \%$, occurred in the Beichuan River region and the headwater region, but still reached the internationally recognized standard of ecological water use proportion, which is higher than 60 to $70 \%$, and the standard of northwest China, which is higher than 50 to $60 \%$ [35]. In addition, groundwater utilization in all water resource partitions could reach the balance of exploitation and supplement. In summation, the ecological water use proportion of the study area was within a reasonable range, and some areas still have a certain development potential as water resources.

\section{River Water Quantity and Quality Evaluation}

For example, we took the Xining and Minhe hydrological stations as typical sections to evaluate the river water quantity and quality. Using the Montana Method to calculate the river's ecological water demand, the minimum river ecological basic flows at the Xining and Minhe Stations 
Table 3. Point source pollutant simulation and analysis result of the main water function areas in datum year (Unit, t).

\begin{tabular}{|c|c|c|c|c|c|c|c|}
\hline \multirow{2}{*}{\multicolumn{2}{|c|}{ Water function areas }} & \multicolumn{2}{|c|}{ Quantity into river } & \multicolumn{2}{|c|}{ Water environment capacity } & \multicolumn{2}{|c|}{ Required reducing quantity } \\
\hline & & \multirow{2}{*}{$\begin{array}{l}\text { COD } \\
199.4\end{array}$} & \multirow{2}{*}{$\begin{array}{c}\begin{array}{c}\text { Ammonia } \\
\text { nitrogen }\end{array} \\
16.9\end{array}$} & \multirow{2}{*}{$\begin{array}{l}\text { COD } \\
227.1\end{array}$} & \multirow{2}{*}{$\begin{array}{c}\begin{array}{c}\text { Ammonia } \\
\text { nitrogen }\end{array} \\
7.6\end{array}$} & \multirow{2}{*}{$\frac{\text { COD }}{0}$} & \multirow{2}{*}{$\begin{array}{c}\begin{array}{c}\text { Ammonia } \\
\text { nitrogen }\end{array} \\
9.3\end{array}$} \\
\hline \multirow{11}{*}{$\begin{array}{l}\text { Huangshui } \\
\text { River }\end{array}$} & $\begin{array}{l}\text { Haiyan Headwater } \\
\text { Conservancy Region }\end{array}$ & & & & & & \\
\hline & $\begin{array}{l}\text { Haiyan Agricultural } \\
\text { Water Consumption } \\
\text { Region }\end{array}$ & 1794.8 & 152.2 & 95.0 & 2.4 & 1699.8 & 149.8 \\
\hline & $\begin{array}{l}\text { Huangyuan Transitional } \\
\text { Region }\end{array}$ & 2009.0 & 130.3 & 214.9 & 6.0 & 1794.1 & 124.4 \\
\hline & $\begin{array}{l}\text { Xining Drinking Water } \\
\text { Source Region }\end{array}$ & 2031.4 & 144.6 & 262.1 & 27.0 & 1769.3 & 117.7 \\
\hline & $\begin{array}{l}\text { Xining West Industrial } \\
\text { Water Consumption } \\
\text { Region }\end{array}$ & 2187.0 & 420.2 & 1167.8 & 61.5 & 1019.2 & 358.7 \\
\hline & $\begin{array}{l}\text { Xining Scenery or } \\
\text { Entertainment Water } \\
\text { Consumption Region }\end{array}$ & 1971.3 & 378.7 & 1052.6 & 42.6 & 918.6 & 336.1 \\
\hline & $\begin{array}{l}\text { Xining East Industrial } \\
\text { Water Consumption } \\
\text { Region }\end{array}$ & 2354.2 & 452.3 & 1257.1 & 75.6 & 1097.1 & 376.7 \\
\hline & $\begin{array}{l}\text { Xining Pollutant } \\
\text { Discharge Control } \\
\text { Region }\end{array}$ & 2988.6 & 574.2 & 1595.9 & 59.6 & 1392.7 & 514.6 \\
\hline & $\begin{array}{l}\text { Pingan Transitional } \\
\text { Region }\end{array}$ & 371.1 & 71.3 & 198.2 & 12.7 & 172.9 & 58.6 \\
\hline & $\begin{array}{l}\text { Ledu Agricultural Water } \\
\text { Consumption Region }\end{array}$ & 1303.2 & 220.0 & 1180.1 & 49.2 & 123.2 & 170.9 \\
\hline & $\begin{array}{l}\text { Minhe Agricultural Water } \\
\text { Consumption Region }\end{array}$ & 4274.3 & 468.2 & 2052.1 & 85.4 & 2222.2 & 382.8 \\
\hline $\begin{array}{l}\text { Beichuan } \\
\text { River }\end{array}$ & $\begin{array}{l}\text { Xining Industrial Water } \\
\text { Consumption Region }\end{array}$ & 7059.4 & 886.9 & 594.3 & 24.7 & 6465.1 & 862.1 \\
\hline \multirow{2}{*}{$\begin{array}{l}\text { Nanchuan } \\
\text { River }\end{array}$} & $\begin{array}{l}\text { Xining Industrial Water } \\
\text { Consumption Region }\end{array}$ & 143.9 & 19.7 & 2.4 & 0.1 & 141.5 & 19.6 \\
\hline & $\begin{array}{l}\text { Xining Scenery or } \\
\text { Entertainment Water } \\
\text { Consumption Region }\end{array}$ & 86.6 & 11.9 & 1.5 & 0.1 & 85.1 & 11.8 \\
\hline \multirow{2}{*}{$\begin{array}{c}\text { Shatangchuan } \\
\text { River }\end{array}$} & $\begin{array}{l}\text { Huzhu Agricultural Water } \\
\text { Consumption Region }\end{array}$ & 1365.3 & 170.3 & 143.5 & 9.1 & 1221.8 & 161.2 \\
\hline & $\begin{array}{l}\text { Xining Industrial Water } \\
\text { Consumption Region }\end{array}$ & 178.1 & 22.2 & 18.7 & 0.8 & 159.4 & 21.4 \\
\hline Total & & 30317.6 & 4139.9 & 10063.1 & 464.2 & 20254.5 & 3675.8 \\
\hline
\end{tabular}

were $3.75 \mathrm{~m}^{3} / \mathrm{s}$ and $6.5 \mathrm{~m}^{3} / \mathrm{s}$, respectively, and the suitable river ecological basic flows were $11.25 \mathrm{~m}^{3} / \mathrm{s}$ and $19.51 \mathrm{~m}^{3} / \mathrm{s}$ According to the requirements of the water function partitions, the water quality of the Xining and Minhe stations should at least reach the standard IV and V levels.

According to the results of a long series of simulations, the guarantee rates of the minimum river ecological basic flows of the Xining and Minhe stations were $100 \%$ and $97.4 \%$, respectively, and the guarantee rates of the suitable river ecological basic flows were 88.3 and $76.7 \%$, respectively. It can therefore be concluded that the river's ecological water demand can be basically satisfied.

Due to the fact that the total pollutants have not been controlled, the guarantee rate simulation results of the water quality reaching standard in the Xining and Minhe stations were only $12.8 \%$ and $67.6 \%$, respectively. This indicated that the water pollution of the local area was very serious. According to the results of water quality simulations, the 
total quantities of COD and ammonia nitrogen in the water of the main function areas were 3.0 and 8.9 times that of their water environment capacity, respectively. In order to satisfy the requirement of total pollutant control, the quantity of point source COD and ammonia nitrogen entering river should be reduced by a minimum of 20.3 thousand tons and 3.8 thousand tons.

The point source COD and ammonia nitrogen simulations and analysis results of the main water function areas are shown in Table 3.

\section{Conclusions}

In this study, three main areas have been researched as follows:

First, this study used a natural-artificial dualistic water cycle method by coupling a supply-demand balance system, a water consumption balance system, and a water quality simulation mode, and then constructing the water quantity and quality integrated evaluation model. In order to realize the dual water supply, the constraint equation of dual water supply was added into the supply-demand balance system. When the integrated evaluation model was operating, the supply-demand balance system could obtain the water allocation decision results, which was based on the nodes' water quantity and quality and provided pollution discharge information for the water quality simulation system; the water consumption balance system simulated the river's runoff process; the water quality simulation model simulated the water quality condition and provided related information for the supply-demand balance system. Overall, the water quantity and quality integrated evaluation model was able to simulate not only the social economic water supply and consumption process, but also the river's water quantity and quality process.

Secondly, this study put forward a water pollutioninduced water shortage quantitative identification method, and an evaluation index of the proportion between social economic water consumption and ecological water use. This evaluation index is suitable not only for whole basin evaluation, but also social economic water consumption evaluation of the water resource partition with inbound and outbound water. This study also evaluates the satisfaction degree of the river's ecological flow and water quality based on natural-artificial dualistic water cycle simulations.

The third focus of this study utilized an application of water quantity and quality integrated evaluation model in the main stream of the Huangshui River (Qinghai, China). The evaluation results showed three points:

1) Source, engineering, and water pollution-induced water shortage all existed in the study area at the time, and the water pollution-induced water shortage was mainly concentrated in the midstream and downstream regions. The water pollution-induced water shortage rate of the whole basin was $3.7 \%$, and some local areas were even higher, reaching $25.7 \%$.

2) The ecological water use proportions of each water resource partition were all higher than $80 \%$. The eco- logical water demand could potentially be satisfied in regards to water quantity, allowing some areas to still have a certain developmental potential as water resources.

3) Due to the total pollutants not having been controlled, water pollution in the study area was considered to be serious and the guarantee rate of the water quality reaching the standard was low. According to the results of the water quality simulation, the total quantities of COD and ammonia nitrogen entering the main river water function areas were 3.0 and 8.9 times that of their water environment capacities, respectively. In order to satisfy the requirement of total pollutant control, the quantity of point source COD and ammonia nitrogen in the river should be reduced by a minimum of 20.3 thousand tons and 3.8 thousand tons.

In this study, there are still the following deficiencies:

1) The study only considered the impact of the groundwater quantity and quality on socio-economic water needs, and did not simulate the impact of water resource development and utilization on groundwater quantity and quality. Therefore, the quantity and quality joint evaluation of the surface water and groundwater requires further study.

2) Only evaluations of the non-point source pollutants were performed and a preliminary simulation was conducted using an output coefficient method. Therefore, non-point source pollution simulations should be the focus of future work.

\section{Acknowledgements}

The study obtained financial support from major science and technology programs for water pollution control and treatment in China (2012ZX07201-006), the Key Study Project of the National Natural Science Foundation of China (50939006), the National 973 Program of China (2006CB403404), key technologies of the "Three Red Lines" river basin management based on the water cycle and its accompanying process (2013ZY02), the Study on Water Ecological Civilization Construction Based on Dualistic Water Cycle and Associated Process Integrated Simulation (2013QN02), and the National Social Science Foundation Youth Project (Grant No. 13CGL091).

\section{References}

1. MILORADOV M., MARJANOVIĆ P. Guidelines for conducting water resources assessment, a contribution to the International Hydrological Programme within Project M.11(a) (IHP-IV). UNESCO, USA. 1998.

2. LUITEN J. P. A., GROOT S. Modeling quantity and quality of surface waters in the Netherlands, policy analysis of water management for the Netherlands. European Water Pollution Control (2), 23, 1992.

3. VIJAYAN G., NATHAN N. S., SUBRAMANIAN R. S. Management of water resources for quality and quantity. Journal of Indian Water Works Association, January-March, pp. 43-46, 1999. 
4. AZEVEDO D. L., GABRIEF T., GATES T. K. Integration of water quantity and quality in strategic river basin planning. J. Water Res. Pl-ASCE 126, (2), 85, 2000.

5. CASTELLETTI A.M. ASCE; YAJIMA H., GIULIANI M., SONCINI-SESSA R., WEBER E. Planning the Optimal Operation of a Multi-outlet Water Reservoir with Water Quality and Quantity Targets. J. Water Res. Pl-ASCE 140, (4), 1, 2014.

6. XIA J., WANG M.L., WANG Z.G., NIU C.W., YAN D. An integrated assessment method of water quality and quantity applied to evaluation of available water resources. Journal of Natural Resources 20, (5), 752, 2005.

7. XIA J., WANG Z.G., YAN D., WANG M.L. An integrated assessment method of water quality and quantity related to surface water resources status. Journal of Natural Resources 21, (5), 146, 2006

8. XIA X. H., ZHANG X., YANG Z.F., SHEN Z.Y., LI D. Integrated water quality and quantity evaluation of the Yellow River. Journal of Natural Resources 19, (3), 293, 2004.

9. XIA X.H., YANG Z.F., SHEN Z.Y. Integrated evaluation of water quality and quantity of Yellow River. Acta Scientiae Circumstantiae 25, (5), 595, 2005.

10. JIA Y.W., NIU C.W., WANG H. Integrated modeling and assessment of water resources and water environment in the Yellow River Basin. Journal of Hydro-Environment Research 1, 12, 2007.

11. JANG C.S., CHEN S.K., KUO Y.M. Establishing an irrigation management plan of sustainable groundwater based on spatial variability of water quality and quantity. J. Hydrol. 414-415, 201, 2012.

12. JAMSHIDZADEH Z., MIRBAGHERI S.A. Evaluation of groundwater quantity and quality in the Kashan Basin in central Iran. Desalination 270, 23, 2011.

13. PISINARAS V., PETALAS C., GIKAS G. D., GEMITZI A., TSIHRINTZIS V. A. Hydrological and water quality modeling in a medium-sized basin using the soil and Water Assessment Tool (SWAT). Desalination 250, 274, 2010.

14. WU M., DEMISSIE Y., YAN E. Simulated impact of future biofuel production on water quality and water cycle dynamics in the Upper Mississippi river basin. Biomass Bioenerg. 41, 44, 2012.

15. LOUKAS A. Surface water quantity and quality assessment in Pinios River, Thessaly, Greece. Desalination 250, 266, 2010.

16. WANG H., CHEN M. J., QIN D. Y. The research of reasonable allocation water resources and carrying capacity in the Northwest of China. Yellow River Conservancy Press, Zhengzhou, China. 2003.

17. WANG H., WANG C. M. Theory of annual runoff evolution under natural-artificial dual mode and case study of Wuding River basin on the middle Yellow River. Science in China Ser. E Engineering \& Materials Science 47, (Supp. I), 51, 2004.

18. JIA Y. W., WANG H., WANG J. H., LUO X. Y. Development and verification of a distributed hydrologic model for the Yellow River Basin. Journal of Natural Resources 20, (2), 300, 2005.

19. JIA Y. W., WANG H., ZHOU Z. H., YOU J. J. Development and application of dualistic water cycle model in Haihe
River Basin, I. Model development and validation. Advances in Water Science 21, (1), 1, 2010.

20. JIA Y. W., WANG H., GAN H., YOU J. J. Development and application of dualistic water cycle model in Haihe River Basin, II. Strategic research and application for water resources management. Advances in Water Science 21, (1) 9, 2010

21. WANG H., WANG J. H., QIN D. Y., JIA Y. W. Theory and methodology of water resources assessment based on dualistic water cycle model. Shuili xuebao 37, (12), 1496, 2006.

22. WANG X.Q., LIU C.M., ZHANG Y. Water Quantity/Quality Combined Evaluation Method for Rivers' Water Requirements of the Instream Environmental Flow in Dualistic Water Cycle, A Case Study of Liaohe River Basin. Acta Geographica Sinica 61, (11), 1132, 2006.

23. WEI C. J., HAN J. S., HAN S. H. Basin/regional water resources optimal allocation key technology and demonstration considering total factor. China Water Power Press, Beijing, China. 2012.

24. MEP, AQSIQ, Environmental quality standards for surface water (GB3838-2002). Beijing, China. 2002.

25. ZHANG S. P., PU Q., LI L. Q., LIAO S. S. Special water resources allocation based on controllable ET. Water Resources Protection 28, (5), 13, 2012

26. YANG D.W., KUSUDA T. Water Resources Unified Assessment Models and Applications in the Yellow River Basin. China Water Resources and Hydropower Publishing, Beijing. 2005.

27. QIN D. Y., LU J. Y., LIU J. H., WANG M. N. Theories and calculation methods for regional objective ET. Chinese Science Bulletin 54, (1), 150, 2009.

28. LIU J. H., QIN D. Y., WANG M. N., LU J. Y. Theories and calculation methods for regional objective ET (evapotranspiration), Applications. SCIENCE CHINA Technological Sciences 52, (5), 1390, 2009.

29. WANG H., YANG G. Y., JIA Y. W., QIN D. Y. Study on consumption efficiency of soil water resources in the Yellow River Basin based on regional ET structure. SCIENCE CHINA Earth Sciences 51, (3), 456, 2008.

30. WANG H., YANG G. Y., JIA Y. W., QIN D. Y. Necessity and feasibility for an ET-based modern water resources management strategy, A case study of soil water resources in the Yellow River Basin. SCIENCE CHINA Technological Sciences 52, (10), 3004, 2009

31. MEI J. S. Features of water function zoning in different river basins in China. China water resources 7, 38, 2012.

32. PENG W. Q. Water function zoning of national key rivers and lakes and its importance. China Water Resources 7, 34, 2012.

33. MWR Code of practice for computation on allowable permitted assimilative capacity of water bodies(GB/T251732010). Standards press of China, Beijing, China. 2010.

34. WEI C. J., WANG H. Generalization of regional water resource deployment network chart. Shuili Xuebao 38, (9), 1103, 2007

35. CAE, Strategic Study on Allocation of Water Resources, Conservation and Upgrading of Eco-environment and Sustainable Development in North-west China. Engineering Science 5, (4), 1-26, 2003 